$1-1-1965$

\title{
Small greenhouse and greenhouse-florist operations in West Virginia
}

Ronnie L. Burke

Robert L. Jack

Follow this and additional works at: https://researchrepository.wvu.edu/ wv_agricultural_and_forestry_experiment_station_bulletins

\section{Digital Commons Citation}

Burke, Ronnie L. and Jack, Robert L., "Small greenhouse and greenhouse-florist operations in West Virginia" (1965). West Virginia Agricultural and Forestry Experiment Station Bulletins. 517.

https://researchrepository.wvu.edu/wv_agricultural_and_forestry_experiment_station_bulletins/478 @ WVU. It has been accepted for inclusion in West Virginia Agricultural and Forestry Experiment Station Bulletins by an authorized administrator of The Research Repository @WVU. For more information, please contact ian.harmon@mail.wvu.edu. 
West Virginia University Libraries

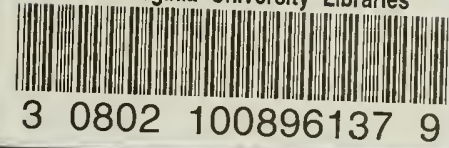





\section{BULLETIN 517 DECEMBER 1965}

SMALL GREENHOUSE

AND GREENHOUSE-FLORIST

OPERATIONS IN

WEST VIRGINIA
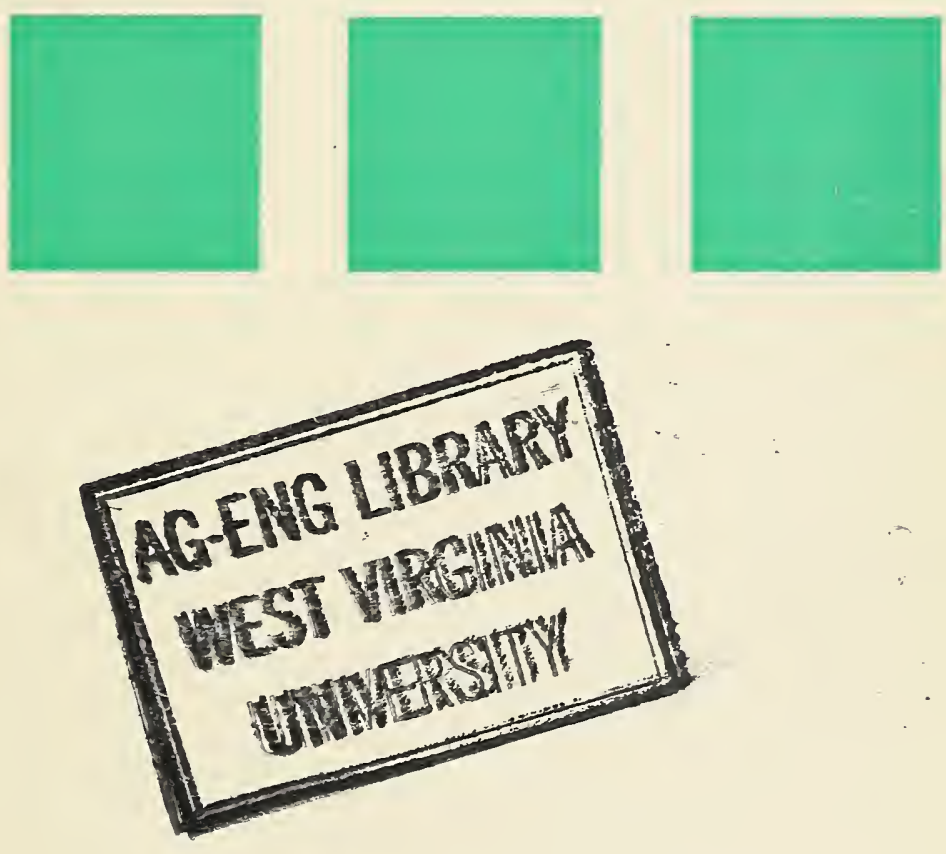

VEST VIRGINIA UNIVERSITY

IGRICULTURAL EXPERIMENT STATION 
Digitized by the Internet Archive in 2010 with funding from

Lyrasis Members and Sloan Foundation 


\section{Contents}

SUMMARY ............................ 3

OBJECTIVES $\ldots \ldots \ldots \ldots \ldots \ldots \ldots \ldots \ldots \ldots \ldots \ldots \ldots \ldots \ldots \ldots \ldots \ldots \ldots$

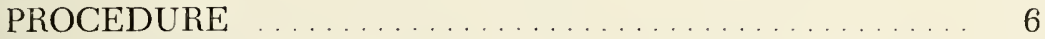

FINDINGS AND ANALYSIS ............... 6

Size of Greenhouse and Trade Center Population ... 6

Grefnhouse-Florist Shop Combination and Funeral Work .................... 8

Number of Emiployees . . . . . . . . . . . . . . . . . . . 10

Volume Produced . . . . . . . . . . . . . . . . . . . 10

Procurement Source and Method of Delivery ...... 10

Frequency of Truck Delivery $\ldots \ldots \ldots \ldots \ldots \ldots \ldots \ldots$

Description of Truck Delivery . . . . . . . . . . . . 13

Stability of the Greenhouse Industry …..... . 15

Methods of Sale ...................... 18 


\section{THE AUTHORS}

Ronnie L. Burke is a Research Assistant and Robert L. Jack is an Assistant Agricultural Economist in the West Virginia University Agricultural Experiment Station.

\section{ACKNOWLEDGMENT}

Special acknowledgment is due Roger $\mathrm{I}^{\mathrm{T}}$. Pease, a retired Assistant Agricultural Economist in the W'est Virginia University Agricultural Experiment Station. Mr. Pease prepared the schedules and supervised collection of the data.

This bulletin is published as a contribution to the Northeast Regional Marketing Research Project, (NEM-S). The West Virginia Research basic to the data included was supported by both state and regional research funds.

W'est Virginia University Agrictluttral Experimext Station College of Agriculture and Forestry

A. H. VanLandinghai, Director MORGANTOWY 


\section{Summary}

BJECTIVES of this study were: (1) to determine the characteristics of small greenhouses and greenhouse-florists producing and marketing floricultural products in West Virginia; (2) to analyse the relationships existing between size of greenhouse and marketing methods, procurement practices, locations, number of employees, volumes of plant material produced; and (3) to establish bench marks for accessing findings of future greenhouse and greenhouse-florist studies.

Data were obtained by personal interviews with 131 greenhouse owners or operators in West Virginia who did not have more than 20,000 square feet of floor space in their greenhouses. A florist shop may or may not have been operated in connection with the greenhouse.

Although the study included only greenhouses with 20,000 or less square feet of floor space, the typical greenhouse in this size group had less than 5,001 square feet. Only 6 of 131 greenhouses had 15,001 to 20,000 square feet of floor space.

A direct relationship existed between size of greenhouse and trade center population. Two-thirds of the greenhouses with 15,001 to 20,000 square feet of floor space served a trade center having more than 50,000 people. About one-half of the greenhouses with less than 1,500 square feet of floor space served a trade center of less than 50,000 people. The data also suggested that a trade center population of 20,000 or more may be needed to support greenhouses with more than 15,000 square feet of floor space.

Slightly more than one-third of the greenhouses were operated in conjunction with florist shops. As the size of the greenhouse increased, there was an increase in the proportion of operations which also operated a florist shop. The majority of these greenhouse-florist combinations, 80.9 per cent, were located on the same premises.

A positive relationship existed between the size of greenhouse and the proportion of operations which specialized in funeral work. As size of greenhouse increased, the proportion of greenhouse-florists which specialized in funeral work also increased.

The average number of full-time employees was 1.9 workers for the 131 greenhouse operations. Small greenhouses usually employed one or two full-time employees and part-time employees. However, large greenhouses employed two or more full-time workers and no part-time workers.

Greenhouse operators in West Virginia tend to produce a larger volume (number) of plants than cut flowers. The majority of the operators produced more than 10,000 vegetable plants, and 22.1 per cent pro- 
duced 5,001 to 10,000 petunia plants per year. One to 1,000 was the volume of plants and cut flowers produced by the largest proportion of the greenhouse businesses.

Forty-eight greenhouse operators had seven-eights or more of their purchased products delivered by public carrier, none of which was by air. Only 15.3 per cent of the operators depended on air service as a delivery method for some of the plant materials purchased. A larger number of greenhouses depended on in-State trucks than on out-of-State trucks as a method for delivering plant materials they purchased.

The frequency of in-State truck delivery exceeded the frequency of out-of-State truck delivery. However, a large proportion of the greenhouses are "never" visited by in-State or out-of-State trucks delivering plant material.

Sixty per cent of the owners were "very satisfied" with in-State truck deliveries. In contrast, only 40 per cent of the owners indicated they were "very satisfied" with deliveries made by out-of-State trucks. A large proportion of the owners indicated that products delivered by in-State trucks were "not of standard quality" and that "much needed is not available." More than one-half of the respondents stated that products delivered by out-of-State trucks "often arrived damaged."

The greenhouse industry in West Virginia seens to be stable in terms of number of years of operation at the same location. Approximately 60 per cent of the greenhouses had operated at the same location for ten or more years. The owners could recall only a few new greenhouses, ownership changes of existing greenhouses, and greenhouses which ceased operations during the ten years preceding 1960 .

There was a direct relationship between size of greenhouse and number of years of operation. The size of greenhouse tended to increase with the number of years that the business had operated at the same location.

The majority of the 131 greenhouse owners, 62.6 per cent, marketed seven-eights or more of their products retail. In comparison, only 7.6 per cent of the owners marketed seven-eights or more of their products wholesale.

The data indicate that a direct relationship existed between size of greenhouse and volume of products sold wholesale. A few of the small greenhouses sold one-half or more of their products wholesale. However, two-thirds of the large greenhouses, 15,001 to 20,000 square feet of floor space, sold one-half or more of their volume wholesale. 


\section{Small Greenhouse and Greenhouse-Florist Operations in West Virginia}

Ronnie L. Burke and Robert L. Jack

R APID CHANGES and adjustments have occurred in the agricultural Rindustry during the last twenty years. New production practices, marketing techniques, and innovations were instrumental in bringing about these dynamic changes and adjustments.

Apparently the floricultural sector of the agricultural industry was partially insulated from the direct influence of the changes and adjustments which occurred in the total agricultural industry. ${ }^{2}$ For example, in West Virginia the wholesale value of cut flowers, flowering and foliage plants, bedding plants, and cultivated florist greens increased 5.2 per cent, while value of cash receipts from farm marketing decreased 5.1 per cent from 1949 to $1959 .{ }^{3}$ During the same period the square feet of greenhouse area in the State used for the production of the floricultural crops decreased 5.2 per cent, while total acres in farms decreased 26.2 per cent. Furthermore, the number of paid employees of the floricultural industry in West Virginia decreased only 2.3 per cent compared to a decrease of 39.7 per cent for the number of hired farm workers.

\section{Objectives}

The objectives of this study were: (1) to determine the characteristics of small greenhouses ${ }^{4}$ and greenhouse-florists ${ }^{5}$ producing and

${ }^{1}$ U. S. Bureau of Census. U. S. Census of Agriculture: 1959, Volume V. Special Reports, Part I-Horticultural Specialties, (U. S. Government Printing Office, Washington, D. C. 1962), pp. 21, 51, 557.

${ }^{2}$ U. S. Bureau of Census. U. S. Census of Agriculture: 1959, Volume I. Counties, Part 25 West Virginia (U. S. Government Printing Office, Washington, D. C. 1961), pp. 3,8 .

${ }^{3}$ West Virginia Department of Agriculture, West Virginia Crop Reporting Service. West Virginia Agricultural Statistics 1951 and West Virginia Agricultural Statistics 1964, (Charleston, West Virginia), pp. 46, 50.

${ }^{4}$ Small greenhouse refers to an area covered by glass or plastic which had 20,000 or less square feet of floor space. In this writing the term small greenhouse will be used to refer to a greenhouse with less than 1,500 square feet of space and the term large greenhouse will be used to refer to a greenhouse with 15,001 to 20,000 square feet of space unless otherwise indicated.

${ }^{5}$ Greenhouse-florist was a combined greenhouse and florist shop operation which had 20,000 or less square feet of floor space in the greenhouse. For convenience, greenhouse operations will refer to greenhouse and greenhouse-florist shop operations. 
marketing floricultural products in West Virginia; (2) to analyse the relationships existing between size of greenhouse and marketing methods, procurement practices, locations, number of employees, volumes of plant materials produced; and (3) to establish bench marks to be used in accessing findings of future greenhouse and greenhouse-florist studies.

\section{Procedure}

Data for this study were obtained by personal interviews with owners or operators of 131 greenhouse and greenhouse-florist operations in WVest Virginia. Responses were recorded by the interviewers on prepared schedules. The sample consisted of owners and operators of all known greenhouses and greenhouse-florists in West Virginia which had no more than 20,000 square feet of floor space in 1960.

\section{Findings and Analysis}

\section{Size of Greenhouse and Trade Center Population}

Since the typical greenhouse in West Virginia is small relative to those in surrounding states, it was necessary for greenhouses to have no more than 20,000 square feet of floor space to be included in this study. Only 131 greenhouses with less than 20,001 square feet of floor space were operating in West Virginia in 1960. Forty-nine of these businesses had less than 1,500 square feet of floor space (Table 1). The number of greenhouses decreased with each successive increase in size class until only six businesses had 15,001 to 20,000 square feet of floor space.

There was a direct relationship between size of greenhouse and trade center population. Slightly more than 66 per cent of the greenhouses with 15,001 to 20,000 square feet of floor space were located in a trade center having a population of more than 50,000 people (Table 1 ). Only 12.2 per cent of the greenhouses with less than 1,500 square feet of floor space served such a heavily populated trade center. On the other hand, 34.7 per cent of the small greenhouses and none of the large greenhouses served a trade center of less than 2,500 people.

The data in Table 1 support the previous statement that the typical greenhouse in West Virginia is relatively small. Furthermore, the data suggest that a trade center population of more than 20,000 may be necessary to support a greenhouse with more than 15,000 square feet of floor space. In 1954, Pease found a similar relationship between size of a nursery and trade center population in West Virginia.

Pease $^{6}$ states that, "Ninety-four per cent of the State's full-time

${ }^{8}$ Roger W. Pease, Some Effects of Location on West Virginia Nurseries Market. ing Ornamental Plants. Agr. Exp. Sta., IVest Virginia University, Bull. 394, February 1957. Morgantown, p. 15. 


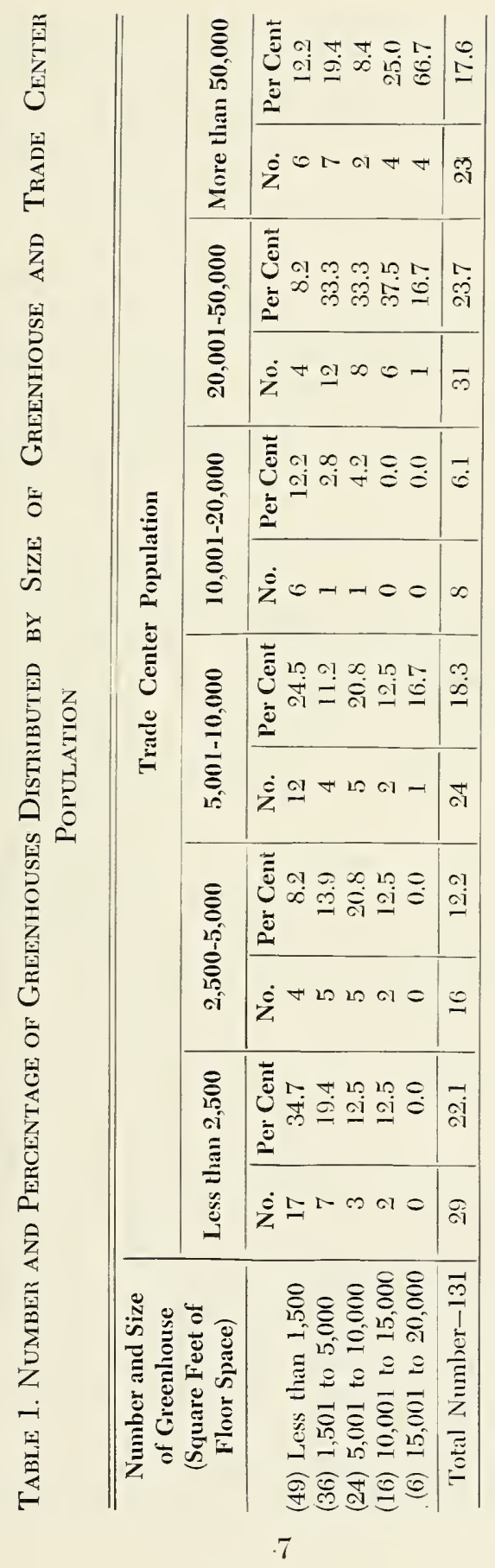


nurseries were clustered in the general vicinities of cities where incorporated and contiguous areas contained more than 20,000 people." He also concluded that, "Apparently service opportunities were inadequate in city areas smaller than 20,000 ; but a few nurseries were prospering in remote locations by marketing wholesale and by affiliation with large nurseries or operating incidentally to other enterprises."

\section{Greenhouse-Florist Shop Combinations and Funeral Work}

Approximately one-third of the 131 greenhouse owners also operated florist shops through which floricultural products were marketed (Table 2). The proportion of greenhouse-florist operations increases with size of greenhouse. Fifty per cent of the large greenhouses are greenhouse-florist operations, whereas only 20.4 per cent of the small businesses fit into that category.

Although the data are not shown in tabular form, 38 of the 47 greenhouse-florist operations had their greenhouse and florist shop located on the same premise. Greenhouses with more than 15,000 square feet of floor space had greenhouse and florist shop for all greenhouse-florist operations on the same premise. The same was true for only 50 per cent of the small greenhouses. For greenhouses with 1,500 to 15,000 square feet, the proportion of greenhouses and florist shops located on the same premise fluctuated from 80 to 93 per cent without establishing a meaningful pattern.

Specialization in funeral work appeared to be directly related to size of greenhouse (Table 2). Only 14.3 per cent of the small greenhouse operators indicated that they specialized in funeral work. This proportion increased with each successive class size until 66.7 per cent of the large greenhouse operators specialized in funeral work.

The proportion of businesses which specialize in funeral work becomes larger if the number of businesses which specialized in funeral work is compared to the number which operated a florist shop for each size category (Table 2). Seven of ten of the small greenhouse-florist operators specialized in funeral work. All of the greenhouse-florist operations having greenhouses with 5,001 to 10,000 and 10,001 to 15,000 square feet specialize in funeral work. All large greenhouse-florist operators and one greenhouse operator without a florist shop specialized in funera work. Although not shown in Table 2, there was a direct relationship be tween the number of years a greenhouse had been in operation at the same location and the proportion of businesses specializing in funera work.

The direct relationship between size of greenhouse, proportion of greenhouse-florists, and proportion of businesses specializing in funera 


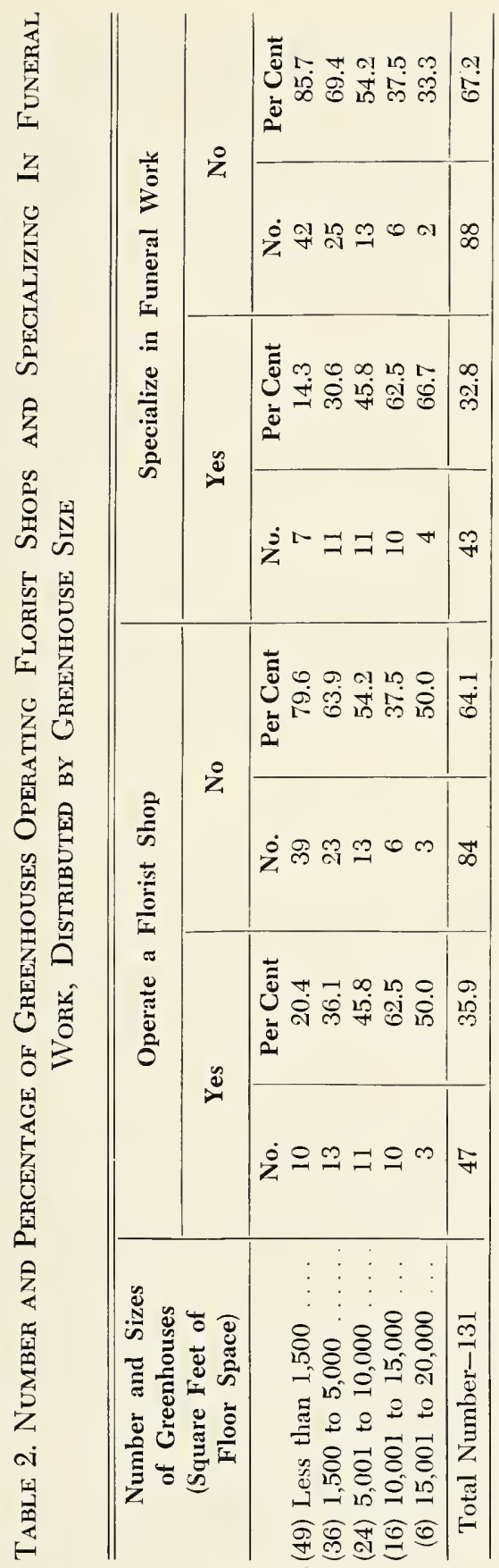


work could be the result of numerous factors. First, a large greenhouse could supply the florist shop with a large variety of plants and plant materials for more months out of the year. Second, large greenhouse operations require more employees. A large number of employees may allow workers to specialize in one type of work such as making floral arrangements for home, special events, or funeral use. Third, it may take a few years for greenhouse-florist operators or their employees to develop skills necessary to make desirable floral arrangements.

\section{Number of Employees}

The average number of full-time employees per greenhouse for the 131 greenhouses was 1.9. Forty-nine per cent of the small greenhouse operations employed one full-time worker, and $2 S .6$ per cent employed part-time workers (Table 3). None of the small greenhouses employed more than two full-time workers. Greenhouses with floor space in excess of 10,000 square feet employed at least two workers, and 68.2 per cent of them employed three or more workers. Greenhouses with less than 5,001 square feet employed all the part-time workers.

As the size of the greenhouse increased, the trend was for the proportion of full-time employees to increase and the proportion of parttime employees to decrease.

\section{Volume of Material Produced}

Considerable variation occurred in type and volume (number) of plants and cut flowers produced by the greenhouses (Table 4). Vegetable and petunia plants were the most popular plants produced. Except for pompon and foliage plants, over 79 per cent of the 131 greenhouses produced some vegetable, petunia, geranium, and miscellaneous plants. No more than 33.6 per cent of the greenhouses produced some of all types of cut flowers (Table 4).

Approximately 40 per cent of the greenhouse operators produced more than 20,000 regetable plants and 22.1 per cent produced 5,001 to 10,000 petunia plants. These two volumes were the most predominate for greenhouses producing vegetable and petumia plants. For all other plant classes, except pompon, the largest proportion of the businesses produced 1 to 1,000 . A volume of 1,001 to 3,000 was most prevalent for snapdragons, standard mums, and miscellaneous cut flowers. For cut flowers produced from bulbs, 1 to 1,000 was the volume produced by the largest proportion of the greenhouse businesses.

\section{Procurement Source and Method of Delivery}

Respondents were asked to designate what fraction of their purchased plant materials came from out-of-State or from in-State concerns, and was delivered by trucks in their area. 


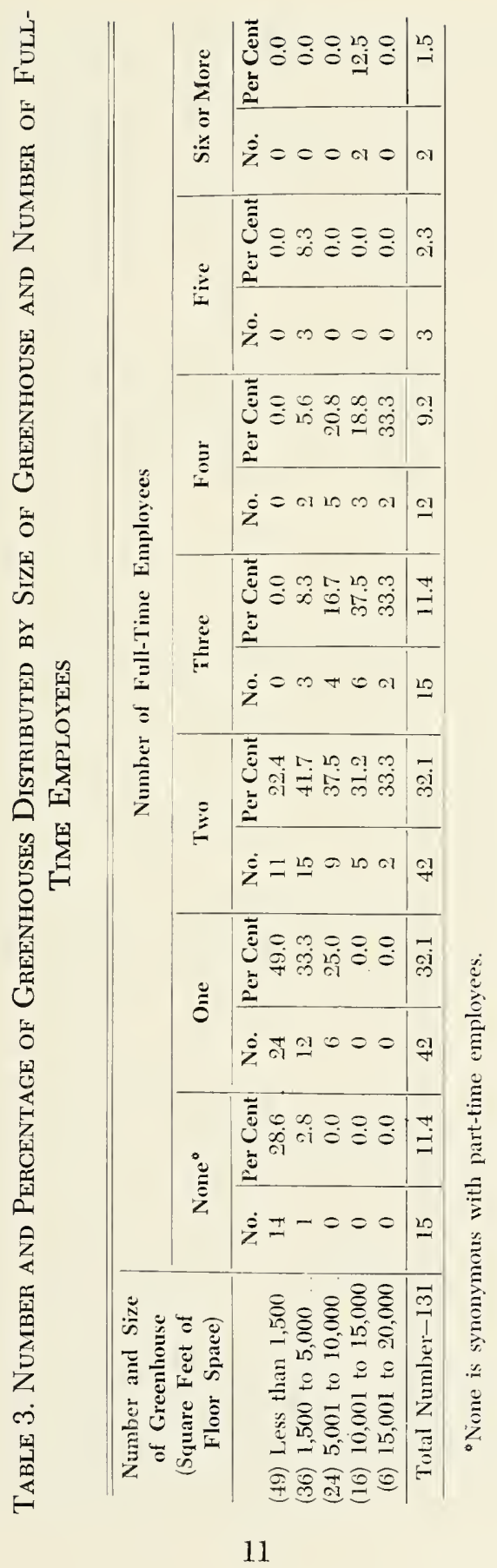




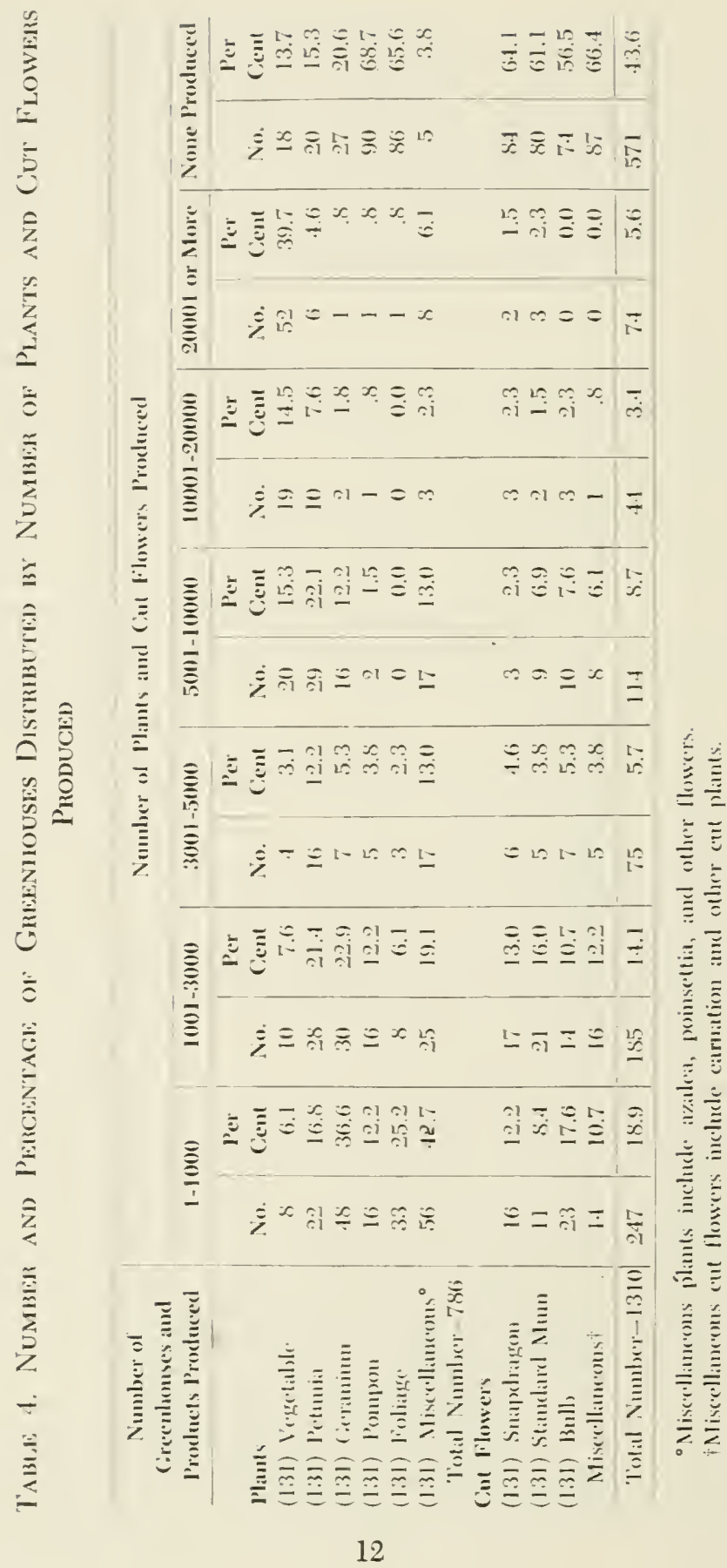


More than 52 per cent of the operators did not buy any of their plant materials from out-of-State concerns and 44.3 per cent did not buy from in-State concerns delivering in the area by trucks (Table 5). Of those that did purchase from out-of-State concerns delivering by truck, 30.5 per cent bought one-eighth or less of their plant materials from these concerns. Twenty-three of the greenhouse operators obtained one-eighth or less of their plant materials from in-State concerns delivering by trucks and 19 purchased seven-eights or more of their plant material from in-State sources.

Although the volume of plant material delivered by air service has been increasing for the floricultural industry, 84.7 per cent of the respondents in this study did not receive any purchased plant material by air. Forty-eight of the greenhouse operators received seven-eights or more of their purchased plant materials by public carriers other than air service (Table 5).

\section{Frequency of Truck Delivery}

Data in Table 5 show that more greenhouse operators buy larger volumes of plant materials from in-State than from out-of-State concerns delivering by trucks. This buying behavior may be partially explained by the frequency of truck delivery by in-State and out-of-State concerns.

Responses concerning frequency of truck delivery in the area show that 46.9 per cent of the greenhouse operations were "never" visited by out-of-State truckers (Table 6). However, only 34.9 per cent were "never" visited by in-State truckers. Responses for other frequency of delivery categories in Table 6 show that in-State trucks visit greenhouse operations more frequently than out-of-State trucks.

\section{Description of Truck Delivery}

Greenhouse owners purchased more plant materials delivered by in-State trucks than by out-of-State trucks. Descriptions by greenhouse owners of in-State and out-of-State truck deliveries were informative. Eighty per cent of the "not standard quality" responses and 100 per cent of "much needed is not available" responses were associated with inState truck deliveries (Table 7). However, 55.6 per cent of the "often arrive damaged" responses were associated with materials delivered by out-of-State trucks.

These data indicate that there are certain disadvantages of both inState and out-of-State truck delivery. However, most greenhouse owners are satisfied with this service regardless of whether in-State or out-ofState truck delivery is used. 


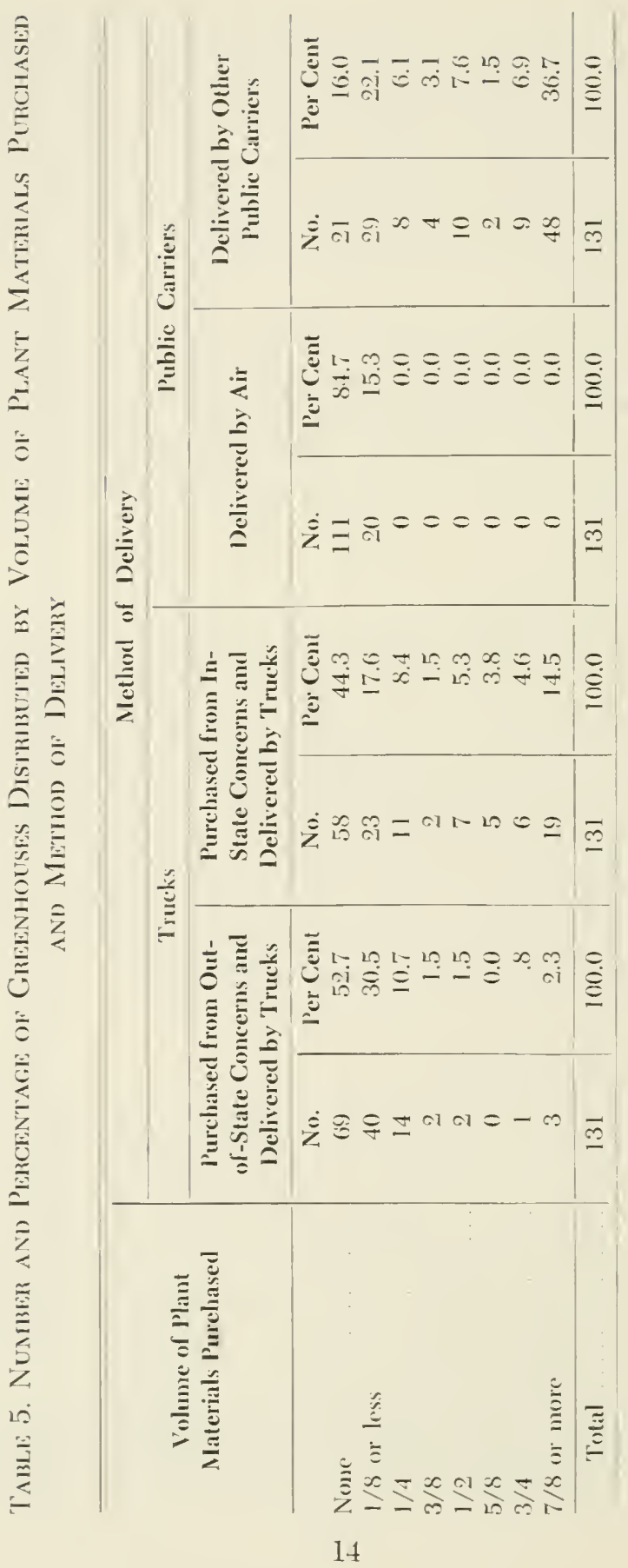


Table 6. Number and Percentage of Greenhouses Distributed by Frequency of Out-of-State and In-State Truck Delivery

\begin{tabular}{|c|c|c|c|c|}
\hline \multirow{2}{*}{$\begin{array}{l}\text { Frequency } \\
\text { of Delivery }\end{array}$} & \multicolumn{4}{|c|}{ Type of Truck Delivery } \\
\hline & \multicolumn{2}{|c|}{ Out-of-State } & \multicolumn{2}{|c|}{ In-State } \\
\hline & No. & Per Cent & No. & Per Cent \\
\hline Daily ......... & 1 & 0.7 & 4 & 3.1 \\
\hline Twice Per Week & 7 & 5.5 & 10 & 7.7 \\
\hline Weekly ............. & 7 & 5.5 & 18 & 14.0 \\
\hline Once Every Other Week & 1 & 0.7 & 0 & .0 \\
\hline Once a Month . . . . . . & 0 & 0.0 & 2 & 1.6 \\
\hline Few Days After Order & 13 & 10.2 & 20 & 15.4 \\
\hline No Regular Time .... & 39 & 30.5 & 30 & 23.3 \\
\hline Never ......... & 60 & 46.9 & 45 & 34.9 \\
\hline Total & $128^{*}$ & 100.0 & $129^{*}$ & 100.0 \\
\hline
\end{tabular}

* Three out-of-State and two in-State comments were made about delivery which were not applicable to classification.

Table 7. Number and Percentage of Respondents Distributed by Description of Plant Materials Delivered by In-State and Outof-State Trucks

\begin{tabular}{|c|c|c|c|c|}
\hline \multirow{2}{*}{$\begin{array}{c}\text { Number of Greenhouses } \\
\text { and Description of } \\
\text { Plant Materials }\end{array}$} & \multicolumn{4}{|c|}{ Type of Truck Route Delivering Plant Materials } \\
\hline & \multicolumn{2}{|c|}{ Out-of-State } & \multicolumn{2}{|c|}{ In-State } \\
\hline $\begin{array}{l}\text { (80) Very Satisfactory . } \\
\text { (17) All-in-all It's The }\end{array}$ & $\begin{array}{r}\text { No. } \\
32\end{array}$ & $\begin{array}{c}\text { Per Cent } \\
40.0\end{array}$ & $\begin{array}{r}\text { No. } \\
48\end{array}$ & $\begin{array}{l}\text { Per Cent } \\
60.0\end{array}$ \\
\hline Best Way to Buy & 6 & 35.3 & 11 & 64.7 \\
\hline $\begin{array}{l}\text { (5) Not Standard Quality } \\
\text { (14) Much Needed is }\end{array}$ & 1 & 20.0 & 4 & 80.0 \\
\hline $\begin{array}{l}\text { Not Available ... } \\
\text { (39) Cheaper Than Can }\end{array}$ & 0 & 0.0 & 14 & 100.0 \\
\hline $\begin{array}{l}\text { Be Grown In } \\
\text { Own Greenhouse } \\
\text { (9) Often Arrive }\end{array}$ & 18 & 46.2 & 21 & 53.8 \\
\hline Damaged . & 5 & 55.6 & 4 & 44.4 \\
\hline
\end{tabular}

\section{Stability of the Greenhouse Industry}

The majority of the greenhouses, 61.1 per cent, have been in operation at the same location for ten or more years (Table 8). Only 20.7 per cent of them have been operating at the same location for less than five years. This distribution takes on a more meaningful pattern when number of years of operation is observed in relation to the size of green- 


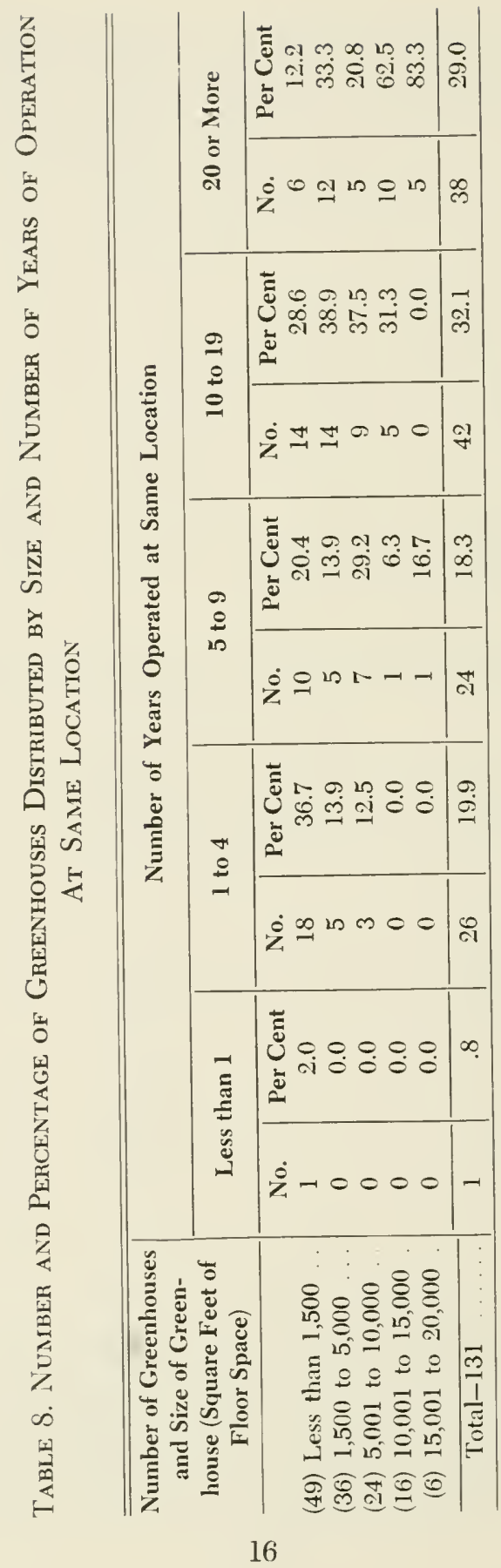


house. Only 12.2 per cent of the small greenhouses have operated at the same location for 20 or more years. However, 83.3 per cent of the large greenhouses have operated at the same location for 20 or more years.

In comparison, 38.7 per cent of the small greenhouses have operated at the same location for less than five years, while none of the large greenhouses have operated for this short period of time.

The above findings indicate that the size of greenhouse is directly related to length of time the greenhouses have been in operation. As owners of new greenhouse operations gain experience and acquire skills the successful ones usually "plow back" part of their earnings into their businesses, thus aiding the growth of their greenhouse business. This behavior may partially explain the direct relationship which exists between size of greenhouse and number of years of operation.

From 1950 to 1960, there was little change in the number of greenhouses in West Virginia. Seventy-nine of the 131 respondents could not remember any greenhouse operations beginning in the ten years prior to 1960 (Table 9). Eighty-four could not remember any greenhouses which had ceased operation between 1950 and 1960, and 88 respondents could not remember any ownership change in greenhouses in their county for the same period.

The stability in the number of greenhouses, indicated by data in Tables 8 and 9 , permits two tenable hypotheses concerning the nature of competition which exists in the greenhouse industry. First, greenhouses established in the industry are making only normal profits. These profits

Table 9. Responses of 131 Greenhouse-Florist Operators Concerning Establishment of New Greenhouses, Change of Greenhouse Ownership and Greenhouses Ceasing Operations in Last Ten Years

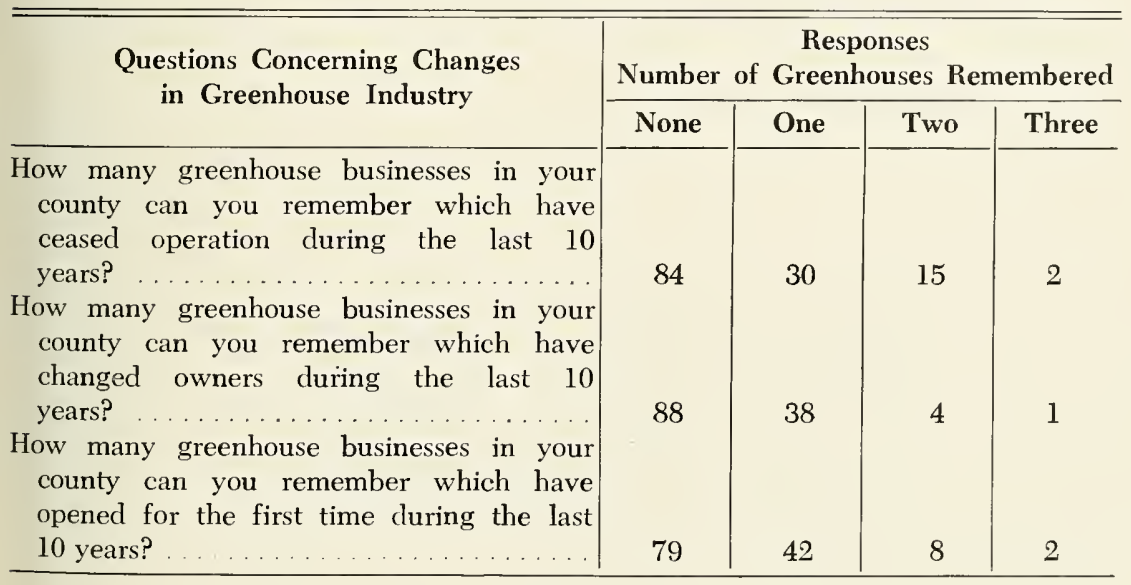


are not large enough to entice new greenhouses to enter the industry. Yet, these profits are large enough to hold established greenhouses in the industry. Second, there are restrictions to entry such as capital requirements, estallished reputations, etc. These restrictions prevent or make it difficult for new firms to enter the greenhouse industry. The former hypothesis concerning normal profits probably is more applicable to the greenhouse industry in West Virginia than is the latter hypothesis.

\section{Methods of Sale}

A large proportion of the greenhouses, 62.6 per cent, marketed seven-eights or more of their products retail, while only 7.6 per cent of the businesses marketed this large a volume wholesale (Table 10). Of the 131 greenhouses, 38.9 per cent did not sell any products wholesale and only 3.8 per cent did not sell any products retail. Only 9.1 per cent of the greenhouses marketed one-fourth or less of their products retail, but 39 per cent marketed one-fourth or less of their products wholesale.

Since large greenhouses could produce volumes of plant materials sufficient to interest wholesalers, it was expected that there would be a direct relationship between size of greenhouse and volume sold wholesale. The data in Table 10 support this expectation. Only 14.2 per cent of the greenhouses with less than 1,500 square feet of floor space sold one-half or more of their volume to wholesalers. However, 66.7 per cent of the greenhouses with 15,001 to 20,000 square feet of floor space sold one-half or more of their volume wholesale. 


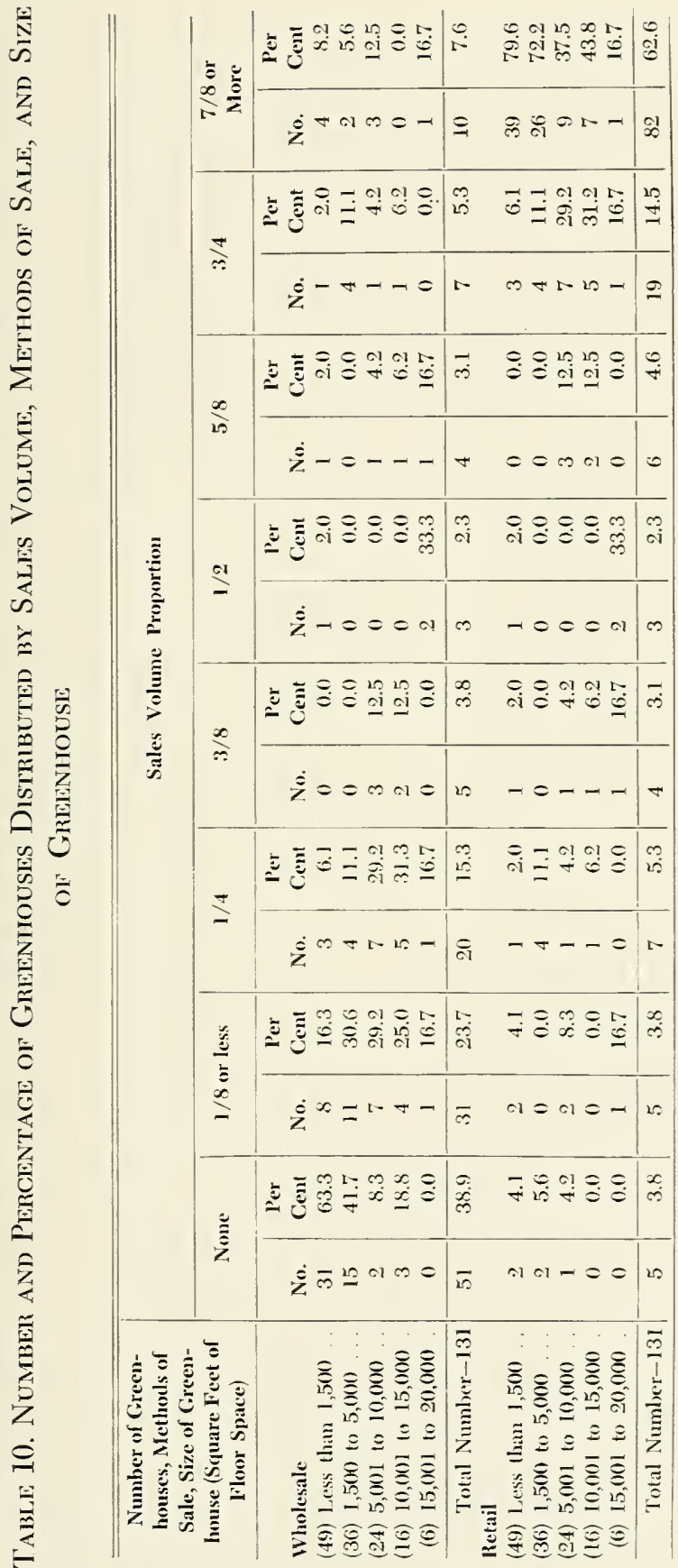






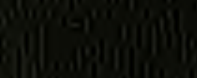

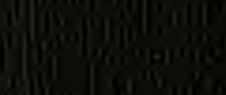

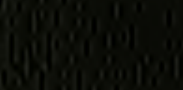

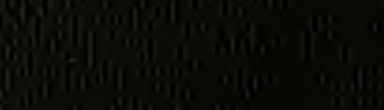

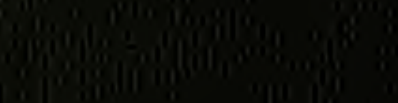
I

年

(t).

Sogs

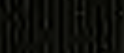

